\title{
EN LOS MÁRGENES DEL PODER, EN PRIMERA LÍNEA DE LAS MANIFESTACIONES OBRERAS: LA REPRESENTACIÓN DE LA MILITANCIA FEMENINA EN EL PARTIDO SOCIALISTA (1906-1927)
}

\author{
MARTA DEL MORAL VARGAS \\ Cañada Blanch Centre for Contemporary Spanish Studies \\ London School of Economics and Political Science
}

Recibido: $15 / 10 / 2010$

Aceptado: 28/11/2010

\section{Resumen}

Este artículo ofrece algunas conclusiones en relación con la imagen y la representación de la Agrupación Femenina Socialista de Madrid (AFSM), que forman parte de una investigación más amplia acerca de las experiencias de acción colectiva femenina en el primer tercio de siglo, en esta ciudad. En primer lugar, presenta una síntesis acerca del proceso de construcción de la identidad colectiva del grupo a lo largo de su historia. Además, compara la imagen proyectada por sus afiliadas con la que difundieron los dirigentes del Partido Socialista. Al mismo tiempo, analiza el espacio de poder efectivo que ocuparon y el poder simbólico que alcanzaron gracias a sus acciones colectivas.

Palabras clave: Historia, relaciones de género, socialismo, Madrid y poder.

\begin{abstract}
This paper shows some of the conclusions about the image and the representation of the Feminine Socialist Group of Madrid, which are part of a larger research project concerning the feminine collective actions in Madrid between 1909-1931. First, it gives an overview about the group's collective identity construction process throughout its history. Furthermore it compares the image built by their affiliates to the one shared by the (male) leaders of the Socialist Party. At the same time, it analyses the effective power space they took up and the symbolic power they reached as a result of their collective actions.
\end{abstract}

Keywords: History, Gender Relations, Socialism, Madrid, Power.

Feminismo/s 16, diciembre 2010, pp. 107-138 


\section{La Agrupación Femenina Socialista de Madrid (1906-1927). El proceso de construcción de una identidad colectiva}

Aunque la Agrupación Femenina Socialista de Madrid (AFSM) no fue la única que integró a las mujeres afiliadas en el Partido Socialista desde su fundación ni en España, ni en Madrid capital, su trayectoria entre 1906-1927 es analizada a lo largo de este artículo para acercarnos a la representación pública de la actividad política de las mujeres en este partido ${ }^{1}$.

Efectivamente, en aquellos años algunas mujeres integraban las filas de las agrupaciones socialistas locales en un número indeterminado pero notablemente inferior al de sus compañeros varones². La fundación de los Grupos Femeninos ha de entenderse en el marco de la aparición de una serie de agrupaciones vinculadas al Partido Socialista, creadas para integrar a ciertos colectivos que no representaban los receptores privilegiados de la propaganda del partido por su privación de derechos políticos (los jóvenes y las mujeres). Pero tal iniciativa no partió de los dirigentes del partido sino de un grupo de militantes establecido en Bilbao a principios del siglo XX, entre quienes se encontraba Virginia González Polo. En esta ciudad, el 12 de julio de 1904, se fundaba el primer grupo de mujeres socialistas de España en un intento por fomentar el interés de las trabajadoras hacia las ideas socialistas ${ }^{3}$.

1. Todos los datos citados en el presente artículo acerca de la historia de esta agrupación en: Del Moral Vargas, Marta. Acción colectiva femenina en Madrid, 1909-1931. Tesis inédita dirigida por la Dra. Gloria Nielfa Cristóbal, UCM, Madrid, 14-XII-2009.

2. La Agrupación Socialista de Madrid (ASM) contó con algunas afiliadas desde 1890 y también durante los años de vida de la AFSM: RALLE, Michel. «Les socialistas madrilènes au quotidien, I (des origines de l'agrupation a 1910)». Mélanges de la Casa de Velázquez, XVII (1981), pp. 323-325 y Del Moral VARGas, Marta. Acción colectiva femenina... Op. cit.

3. En 1904 se fundaba en Bilbao el primer Grupo Femenino Socialista de España por iniciativa de Virginia González y varios dirigentes de la Juventud Socialista. Además, he podido documentar la creación de más de 30 grupos femeninos en otras localidades entre 1904 y 1927: Del Moral VARGAS, Marta. Acción colectiva... Op. cit. y «El Grupo Femenino Socialista de Madrid (1906-1914): pioneras en la acción colectiva femenina». Cuadernos de Historia Contemporánea, 27, (2005), pp. 247-269. A Mary Nash le corresponde la publicación de un primer acercamiento a la AFSM en su tesis Mujer y movimiento obrero en España, 1931-1939, Barcelona, Fontamara, 1981. En el mismo

Feminismo/s 16, diciembre 2010, pp. 107-138 
La intervención de las Juventudes Socialistas en la creación de los Grupos Femeninos queda clara a partir de testimonios como las actas del Comité de la AFSM en las que se afirmaba que «la Juventud es la que constituyó el Grupo» ${ }^{4}$. Tomás Meabe, Luis Riñón, Benito López, Dionisio M. de Aguirre, Gregorio García, José San Pedro inspirados por las recomendaciones adoptadas en el V Congreso de la Internacional Socialista (París, 1900) habían decidido unos años antes promover una organización de jóvenes orientada a oponerse al militarismo a imagen de la Jeune Garde belga. En los primeros momentos, según las resoluciones del Congreso de Stuttgart (1907) admitieron a las trabajadoras como afiliadas. Años después, a raíz de la creación de Grupos Femeninos, los estatutos de las JS aclaraban la obligatoriedad de que las jóvenes ingresaran preferentemente en los grupos de mujeres, si estos existían en su localidad. En caso contrario, podrían ser admitidas en la JS $S^{5}$.

Además de ese contexto internacional favorable, el grupo de Bilbao disponía de recursos para promover sus iniciativas: un órgano de prensa desde 1903, un Centro Obrero, una red de trabajadores jóvenes receptivos a sus acciones de propaganda, pautas organizativas y estrategias para la acción y el aliento de los promotores de las JS y los GFS. Por otra parte, el contexto político nacional, aunque no fomentaba el asociacionismo obrero, no prohibía expresamente ni la militancia juvenil ni la femenina en las agrupaciones políticas $^{6}$. De este modo, el centro de poder del partido en Madrid compuesto por varones cincuentenarios y sexagenarios se encontró con el hecho consumado de la aparición de los grupos de jóvenes y mujeres, tolerándolas no sin

sentido, aunque posterior, BIZCARRONDO, Marta. «Los orígenes del feminismo socialista en España». En La mujer en la Historia de España (siglos XVI-XX), Actas de las II Jornadas de Investigación Interdisciplinaria. Madrid, SEM de la UAM, 1984, pp. 137-159.

4. GFSM, Actas Comité, 17-V-1906/12-III-1910, FPI, Archivo y Biblioteca, [FPI/AASMLXXV-3]. SABORIT, Andrés. Apuntes históricos: Pablo Iglesias, UGT, PSOE. Original mecanografiado. FPI, Archivo y Biblioteca, AASD XXVII-XXXVI, pp. 1011 y 1013: «Creamos el GF, como una sección dentro de la JS».

5. Rosal, Amaro del. Los congresos obreros internacionales en el siglo XX. Barcelona, Grijalbo, 1971, pp. 40-42. Proyecto de reglamento para la FJSE: Renovación, X-1915.

6. Así como la Ley Electoral de 1890 excluía específicamente como electores y elegibles a las mujeres, la legislación sobre derechos y libertades enunciaba de forma genérica el derecho de asociación (Ley de reuniones de 1880 y Ley de asociaciones de 1887). Desde su entrada en vigor, en el Registro de Asociaciones se dieron de alta entidades integradas por mujeres por lo que entiendo que no existía una oposición fuerte a que esto sucediese, como sí ocurría en Alemania en aquellos años. EsTEBAN, Jorge de. Constituciones españolas y extranjeras. Madrid, Taurus, 1979, pp. 267-279. FernÁNDEZ, Arturo. Leyes electorales españolas de diputados a Cortes en el siglo XIX. Estudio histórico y jurídicopolítico. Madrid, Civitas, 1992, pp. 172-202. Leyes políticas. Madrid, Consultor de los Ayuntamientos y juzgados municipales, 1908, pp. 79-85 y 95-107. 
reticencias ${ }^{7}$. Estos jóvenes, situados en los márgenes del poder, no se oponían necesariamente a la disciplina dictada desde la capital pero estaban cargados de iniciativas propias con la intención de ver crecer el partido y la afiliación. Formaban parte de una nueva generación y estaban firmemente convencidos de los planteamientos socialistas en torno a los que se forjaban sus identidades como militantes. Su propia subjetividad les condujo a asumir las recomendaciones internacionales en relación con la militancia juvenil y femenina, mientras que el temor a la disidencia y al radicalismo, y el menosprecio consciente o inconsciente hacia otros sectores que no respondieran al ideal del obrero maduro militante provocaron los recelos de la directiva hacia los grupos recién creados.

Pero, ¿por qué Virginia González y quienes la apoyaron en la idea de fundar GFS defendieron la militancia segregada de las mujeres en el partido? El hecho de que el partido no concibiera a las mujeres como destinatarias imprescindibles de su propaganda por carecer de derechos políticos, por considerar que la militancia era un asunto masculino, por la falta de instrucción de la mayoría de ellas y por su inclinación a defender las doctrinas católicas... debió de provocar un doble efecto. Por un lado, que muy pocas se decidieran a afiliarse al partido y a los sindicatos de clase y, por otro, que las que lo hicieron buscaran la manera de atraer a sus compañeras a las agrupaciones. Fundar una asociación dentro del partido destinada a ellas de manera específica haría posible realizar una propaganda concebida exclusivamente para ocuparse de la situación de las obreras. En segundo lugar, creaba un espacio de reunión

7. Pablo Iglesias había asistido personalmente a los congresos en los que se adoptaron las resoluciones relacionadas con el fomento de estos grupos: ROSAL, Amaro del. Los congresos obreros internacionales en el siglo XIX: de la joven Europa a la Segunda Internacional. México, Grijalbo, 1958, pp. 362, 373, 384, 406 y 417 y Los congresos obreros internacionales en el siglo XX... Op. cit., pp. 14 y 26 y 40-42. La discusión entre Luis Riñón y Pablo Iglesias por la creación de las Juventudes y la oposición de las agrupaciones locales en: CDMH, PS-Bilbao, 174-2; GonzÁlez Quintana, Antonio y MarTín NájERA, Aurelio. Apuntes para la historia de las Juventudes socialistas de España. Madrid, FPI, 1983, pp. 3-23. GONZÁlEZ QUINTANA, Antonio. «La primera organización de jóvenes proletarios españoles: las Juventudes socialistas de España o el fracaso de una alternativa juvenil de clase (1903-1921)». Studia Historica. Historia Contemporánea, 5:4 (1987), pp. 40-41; GILlESPIE, Richard. Historia del Partido Socialista Obrero Español, Madrid, Alianza, 1991, pp. 53-54; DE LuIS, Francisco. «Las Juventudes Socialistas como frente cultural pedagógico del socialismo español: el caso madrileño, 1903-1914». Historia Contemporánea, 8 (1992), pp. 249-250. González Quintana, Antonio, Martín Nájera, Aurelio y GóMEZ BRAVO, Gutmaro. Juventudes Socialistas 100 años protagonistas del cambio. Madrid, Fundación Tomás Meabe, 2006, pp. 50-56. BOURDIEU, Pierre. La dominación masculina. Barcelona, Anagrama, 2000 y Razones prácticas, sobre la teoría de la acción. Barcelona, Anagrama, 1997.

Feminismo/s 16, diciembre 2010, pp. 107-138 
y discusión inexistente para las mujeres que les animaría a participar y, al mismo tiempo, a desarrollar sus propias inquietudes independientemente de los varones.

Por su parte, la experiencia de la AFS de Madrid fue una de las más significativas no solo por el medio millar de militantes que consiguieron afiliar -cifra escasa en comparación con otros grupos socialistas europeos, pero considerable en el panorama español de la época-, sino porque llegó a representar un referente clave para las socialistas de todo el país. La AFSM fue un grupo sólidamente constituido que, aun plasmando un proyecto que en principio le era ajeno, fue capaz de desarrollar su propia versión del mismo y obtener grandes éxitos en Madrid y en todo el país a través de algunas de sus campañas.

En su fundación, el 25 de marzo de 1906, participaron quince mujeres y seis varones. Las militantes socialistas decidieron integrar su propio grupo segregado del de los hombres para poder actuar por su cuenta, para asegurarse un espacio desde el que trabajar por el socialismo ${ }^{8}$. Un espacio privado para el debate, para la discusión de sus propias preocupaciones como trabajadoras socialistas. El nexo común era el ideal político mientras que la necesidad de actuar por su cuenta se imponía como condición imprescindible para hacer oír las demandas formuladas desde su propia subjetividad femenina. Y es que aún en el XI Congreso del Partido Socialista (1918) Virginia González, una de sus principales impulsoras, tuvo que insistir en defender el sentido que encerraba la militancia segregada de las mujeres socialistas:

(Virginia González) se extrañó de que esta cuestión haya podido ser tema en las discusiones de tres Congresos, y defendió la subsistencia de los Grupos Femeninos, argumentando que todos los seres necesitan un ambiente adecuado para desenvolverse, y demostrando que las mujeres socialistas pueden prestar más servicios a la idea y al Partido en sus Grupos, que entremezcladas en las agrupaciones varoniles ${ }^{9}$.

La iniciativa partió de un sector estrechamente vinculado al corazón del partido en Madrid, a imagen de la experiencia iniciada por las socialistas de Bilbao cuya inspiración provenía directamente del socialismo europeo. Clara Zetkin, líder del movimiento de mujeres alemanas y referente fundamental, se había convertido en la máxima responsable de la edición del órgano de prensa del movimiento de mujeres, Die Gleichheit (Igualdad) que comenzó a publicarse a finales de 1891. Al mismo tiempo, sus intervenciones en los congresos

\footnotetext{
8. Sobre la fundación de la AFSM ver Del Moral VArgas, Marta. Acción colectiva... Op. cit. y «El Grupo Femenino...» Op. cit.

9. El Socialista, 28-XI-1918.
} 
socialistas fueron clave para la definición del papel de las mujeres en las luchas obreras. Además, según la prensa socialista, contaban con otros modelos como las socialistas neoyorquinas, cuyo grupo se fundó en 1897, las italianas, desde 1900, las noruegas desde 1901 o las británicas, desde 1906. Estudios más recientes resaltan las organizaciones de mujeres socialistas austriacas, con 7.000 afiliadas en 1904, que llegarían hasta 20.058 en 1913, o las finlandesas, con 10.000 socias en $1905^{10}$.

Sin embargo, en Madrid, esa voluntad de implicación segregada en la lucha política topó con las resistencias de algunas mujeres que, aunque afiliadas, no entendían la necesidad de situarse en primera línea sino que preferían apoyar de forma pasiva la labor de la militancia masculina del partido. En aquellos primeros años del siglo XX, esa opinión era compartida por la mayoría de sus compañeros para quienes las mujeres debían dejar la esfera de lo público para los varones. De nuevo, el sistema de género hegemónico se superponía a la clase. No es casualidad que fueran los sectores más proclives a la introducción de cambios, los menos inmovilistas, en definitiva las Juventudes Socialistas (JS), quienes impulsaron el nacimiento de los grupos femeninos ${ }^{11}$.

Durante los primeros años, las afiliadas al grupo de Madrid concibieron la igualdad como una consecuencia más del advenimiento del socialismo que era, en realidad, el objetivo central de su labor de propaganda. El activismo político se convirtió en una pieza clave de la identidad común que estaban construyendo, y que giraba en torno a la importancia de ser receptoras y propagadoras del mensaje societario y socialista entre las mujeres. Este elemento se mantuvo presente hasta la disolución del grupo en mayo de 1927.

10. Los referentes ideológicos socialistas en relación con las mujeres: BEBEL, August. La mujer y el socialismo (1878), ENGELS, Friedrich. El origen de la familia, la propiedad privada y el Estado (1884). RosAL, Amaro del. Los congresos obreros internacionales en el siglo XIX... Op.cit., pp. 378 y 386 y Los congresos obreros internacionales en el siglo XX... Op.cit., pp. 37 y 39. NASH, Mary. Mujer y... Op. cit., pp. 119-132. EvANS, Richard. Las feministas. Los movimientos de emancipación de la mujer en Europa, América y Australasia, 1840-1920. Madrid, Siglo XXI, 1980, pp. 167-220. La Lucha de Clases, 8-VI1907 y 23-XI-1907. KLEJMAN, Laurence y ROCHEFORT, Florence. L'égalité en marche. Le féminisme sous la Troisième République. Paris, Presses de la Fondation Nationale des Sciences Politiques, 1989, pp. 211-217. SOWERWINE, Charles. Les femmes et le socialisme. Paris, Presses de la Fondation Nationale des Sciences Politiques, 1978. Sobre Clara Zetkin y el movimiento de mujeres en Alemania: OfFEN, Karen. European feminisms, 1700-1950. Stanford, Stanford University Press, 2000, pp. 165-168; NASH, Mary. Mujeres en el mundo. Historia, retos y movimientos. Madrid, Alianza, 2004, pp. 89-95 y Mujer y... Op. cit., pp. 119-132; Bock, Gisela. La mujer en la historia de Europa. Barcelona, Crítica, 2001, pp. 175-179.

11. GonZÁlez Quintana, Antonio y Martín Nájera, Aurelio. Apuntes... Op. cit. González QUINTANA, Antonio. «La primera...» Op. cit., pp. 21-46.

Feminismo/s 16, diciembre 2010, pp. 107-138 
En este sentido, se trata de una identidad que combinaba el sentido relacional y el individualizado ${ }^{12}$. Era individualizada al concebirse a sí mismas como protagonistas de la lucha proletaria, responsables de la propaganda activa entre sus compañeras. Las fundadoras y colaboradoras del núcleo inicial fueron capaces de tomar conciencia de sí mismas, de trascender el cometido que la sociedad les asignaba y de cuestionar el orden social en el que vivieron para optar por una militancia activa y segregada. Asumieron un compromiso político completamente inusual para las mujeres españolas de principios de siglo, cuyo cometido se resumía en asegurar la subsistencia de su familia. Tomar parte en asuntos políticos o ideológicos, en actos de proselitismo, tener ideas, no solo era algo impropio de mujeres sino extraño a la mayoría de la población trabajadora temerosa de significarse en este sentido. Había que conocer muy bien los argumentos socialistas, estar profundamente convencidas de su razón y de la eficacia de los procedimientos para la acción que defendían. Y reunir todas esas condiciones en una misma persona no era algo usual entre las clases populares ni en el Madrid ni en la España de 1906, y menos aún entre las mujeres. Por otra parte, creo que albergaba un componente relacional porque el objetivo último que persiguió la creación de GFS era ser «un auxiliar de la emancipación social» ${ }^{13}$. En el fondo las mujeres vivían su labor como una contribución para el cambio social cuyos beneficios redundarían en toda la población.

La actitud de estas mujeres se alejaba notablemente de las recomendaciones que inspiraban el modelo de ángel del hogar, hegemónico como ideal en la sociedad española del momento, al adoptar un posicionamiento político autónomo y al tomar parte activa en la propaganda socialista, invadiendo el espacio público y desatendiendo, desde aquella perspectiva, su única misión vital como madres y esposas. De este modo, iban más allá que las mujeres que

12. HeRnANDO, Almudena. «El espacio no es necesariamente un lugar. En torno al concepto de espacio y a las implicaciones de su uso en la Prehistoria», Arqueología espacial, 21 (1999), pp. 7-27. Individualización se entiende como la capacidad de «adoptar la posición de «sujeto»-en el sentido moderno del término- dentro de la realidad, de agente de transformación de sus fenómenos o de las acciones que en ella tienen lugar, de alguien en quien reside la iniciativa y la capacidad para esa transformación», en HERNANDO, Almudena. «Poder, individualidad e identidad de género femenina». En A. Hernando (coord.). ¿Desean las mujeres el poder? Madrid, Minerva, 2003, p. 93. HERNANDO, Almudena. «Hombres del tiempo y mujeres del espacio: individualidad, poder e identidades de género». Arqueología espacial, 22 (2000), p. 33.

13. Para Andrés Saborit, la AFSM jamás logró completar esa misión: SABORIT, Andrés. «Recuerdos del tiempo joven». El Socialista, 15-IV-1954, citado por GonZÁLEZ QuinTANA, Antonio. «La primera...» Op. cit., p. 30, nota 25. 
fueron definiendo un modelo de mujer fuerte $e^{14}$ entre las clases trabajadoras, al abandonar el espacio privado no solo para cumplir con su rol tradicional de conservadoras de vida sino para cuestionar su situación y la de la clase obrera en general y demandar cambios en el sistema político y en la legislación laboral. En ese sentido se aproximaban avant la lettre a la mujer moderna, en su faceta de mujer que decide por sí misma, aunque desde mi punto de vista no se pueden asimilar ambos modelos. Además, afirmo que hicieron todo aquello al mismo tiempo que atendían sus obligaciones como madres y esposas, aunque desde la ideología de la domesticidad se reprobara su actitud y se les acusase de lo contrario por no concebir como algo posible que pudieran realizar ambas tareas a la vez $z^{15}$.

Se trataba de mujeres que habían desarrollado un grado de individualización suficiente como para plantearse de forma crítica su situación en el mundo que les había tocado vivir, optar por una alternativa que reparase ese estado y adoptar un plan de acción colectiva en compañía de aquellas y aquellos con quienes compartían una definición concreta de la realidad. Independientemente de su opción política, las mujeres que se adaptaron a este esquema en aquellos años encarnaron un modelo con escasos referentes en la sociedad de la época. Eran mujeres que disfrutaban de una instrucción suficiente para estar al tanto de las noticias, las valoraciones y las propuestas sugeridas como alternativas para modificar la sociedad ${ }^{16}$. Los planteamientos

14. Llona, Miren. Entre señorita y garçonne: historia oral de las mujeres bilbaínas de clase media (1919-1939). Málaga, Universidad de Málaga, 2002.

15. OfFEN, Karen. «Definir el feminismo: un análisis histórico comparativo». Historia social, 9 (1991), pp. 116-128; NASH, Mary. «Identidades, representación cultural y discurso de género en la España contemporánea». En P. Chalmeta, F. Checa y otros. Cultura y culturas en la historia, 94 (1995), pp. 195-203 y LlonA, Miren. Op. cit., pp. 159-306.

16. Las cifras de alfabetización de las afiliadas a la AFSM fueron superiores a los valores correspondientes a las mujeres españolas y a las mujeres de Madrid capital durante toda la vida de la agrupación: por ejemplo, en 1900, Madrid estaba situada a la cabeza de las provincias con mayores tasas de alfabetización femenina: el 53,3\% de las mujeres de la ciudad sabían leer y escribir. En España, en esa fecha el analfabetismo alcanzaba al $71,4 \%$ de las españolas y al $51,8 \%$ de los españoles con respecto al total de la población del país. Si descontamos a los menores de 10 años el analfabetismo alcanzaba entonces al $66 \%$ para las mujeres y al $45,3 \%$ para los hombres. Entre las afiliadas a la AFSM en 1906, el $87,5 \%$ y el $75 \%$ sabían leer y escribir, respectivamente. El análisis sociodemográfico de las afiliadas a la AFSM que se incluye en la tesis ya citada se ha elaborado a partir de: GFSM, Registro de asociadas, 1906/1927, FPI, Archivo y Biblioteca, [FPI/AASM-LVIII-1] y AVM, Padrones Municipales de Habitantes, Madrid, 1905, 1910, 1915, 1920, 1925, 1930. Las tasas de alfabetización para España y Madrid en: CAPEL, Rosa Mª. El trabajo y la educación de la mujer en España, (1900-1930). Madrid, Ministerio de Cultura, Instituto de la Mujer, 1986, pp. 361-379. Sobre la formación de las mujeres dentro del socialismo: DE LUIS, Francisco. La cultura socialista en España,

Feminismo/s 16, diciembre 2010, pp. 107-138 
doctrinales, las crónicas sobre la situación nacional e internacional, las estrategias, las acciones, los discursos aglutinadores del movimiento obrero,... se convertían en herramientas a su alcance en la Casa del Pueblo, donde transcurrían sus reuniones. Contaban, de este modo, con los recursos necesarios para dedicarse a la actividad política y propagandística. Y, sobre todo, eran capaces de presentarse ante la sociedad como individuos autónomos, con ideas, y con derecho a expresarlas y tratar de influir en el devenir del país ${ }^{17}$.

Todos estos elementos fueron una constante en las líderes de muchas de las acciones del periodo, especialmente de aquellas que se caracterizaron por integrar un proyecto bien definido y con una relativa proyección temporal. Su identidad no descuidaba el rol femenino asignado a las mujeres de la época como madres y esposas, aunque eran capaces de entenderlo de diversas formas y lo hacían compatible con esa faceta profundamente independiente y resuelta en el terreno de la política que rompía radicalmente con el modelo femenino ideal. La culminación del proceso de individualización favorecido, entre otras cosas, por el acceso a la educación en el nuevo modelo de representación abstracta de la realidad fue clave en el desarrollo de las trayectorias biográficas de estas mujeres en el tránsito hacia la Modernidad de la sociedad española de principios del siglo $\mathrm{XX}^{18}$. En repetidas ocasiones transgredieron

1923-1930: propósitos y realidad de un proyecto educativo. Madrid, Universidad de Salamanca, CSIC, 1993, pp. 40-45.

17. Como antecedente fundamental responden a este arquetipo las librepensadoras y laicistas que, como Belén Sárraga a finales del siglo XIX, habían protagonizado acciones, siendo detenidas por ello y obteniendo eco y respaldo en la prensa republicana: RAMOS, $\mathrm{M}^{a}$ Dolores. «Hermanas en creencias, hermanas de lucha. Mujeres racionalistas, cultura republicana y sociedad civil en la Restauración». Arenal, 11:2 (2004), pp. 2756; «La República de las librepensadoras (1890-1914): laicismo, emancipismo, anticlericalismo». Ayer, 60 (2005), pp. 45-74; «Feminismo y Librepensamiento en España. Contra las raíces de la sociedad patriarcal». En C. Canterla (coord.). VII Encuentro de la Ilustración al Romanticismo. Cádiz, Universidad de Cádiz, 1994, pp. 313-330; «La construcción de la ciudadanía femenina: las librepensadoras (1898-1998)». En C. Fagoaga (coord.). 1898-1998. Un siglo avanzando hacia la igualdad de las mujeres. Madrid, CAM, 1999, pp. 91-116; «La cultura societaria del feminismo librepensador (1895-1918)». En D. Bussy Genevois (dir.). Les Espagnoles dans l'histoire. Une sociabilité démocratique, (XIXe-XXe siècles). Presses Universitaires de Vincennes, Saint-Denis, 2002, pp. 103-124. SANFeliu, Luz. Republicanas: identidades de género en el blasquismo (1895-1910), Valencia, Universidad de Valencia, 2005, pp. 99-101.

18. HeRnANDo, Almudena. Arqueología de la identidad. Madrid, Akal, 2002, p. 46; «Poder, individualidad...» Op. cit.; «¿Por qué hablar de la subjetividad femenina?» y «Factores estructurales asociados a la identidad de género femenina. La no-inocencia de una construcción socio-cultural». En A. Hernando (coord.). La construcción de la subjetividad femenina. Madrid, Instituto de Investigaciones Feministas, UCM, 2000, pp. 9-11 y 102-103; «Hombres del tiempo...» Op. cit., pp. 26-27. Sobre la exclusión de las mujeres del proyecto ilustrado la autora cita, entre otros, a: AMORÓs, Celia. Tiempo de 
los márgenes establecidos por el sistema de género, dando forma a una nueva identidad femenina clave en los años treinta. Podríamos hablar de un primer paso hacia la profesionalización de la actividad política entre las mujeres, para calificar este modelo que estaba comenzando a construirse y establecer una categoría como herramienta que resumiera todos los rasgos presentes en las líderes socialistas. A este referente se ajustarían las fundadoras de la AFSM que decidieron hacer acto de presencia en la escena pública para defender una concepción autónoma de la situación social de las mujeres de clase obrera. Sin embargo, no creo que la idealización de esta ocupación existiera como referente en su imaginario sino que, más bien, se iría construyendo a partir de los ejemplos representados por algunas pioneras a partir de los años finales del siglo XIX. La resonancia pública de la actividad de ciertas militantes como Virginia González, Juana Taboada, Claudina García,... añadió elementos a ese modelo que, sin duda, influyó en el aumento de la afiliación socialista de los años siguientes. Pero dicho ejemplo no fue privativo de las socialistas sino que también se ajustó a las trayectorias de las líderes de otros proyectos para la movilización femenina como Carmen de Burgos y Consuelo Álvarez, o María de Echarri y Mercedes Quintanilla, para el sindicalismo católico ${ }^{19}$.

Por otro lado, el proceso de construcción de la identidad colectiva de un grupo como éste permanece activo a lo largo de toda la vida del mismo, experimentando transformaciones como producto de la renegociación constante entre sus integrantes ${ }^{20}$. El interés por difundir los ideales socialistas y socie-

feminismo. Sobre feminismo, proyecto ilustrado y postmodernidad. Madrid, Cátedra, 1997 y FrAISSE, Geneviève. Musa de la Razón. La democracia excluyente y la diferencia de los sexos. Madrid, Cátedra, 1991. También Pateman, Carole. El contrato sexual. Barcelona, Anthropos, 1995, con respecto a su marginación de los derechos políticos. Sobre los responsables de la naturalización de la diferencia sexual en España: NASH, Mary. «Experiencia y aprendizaje: la formación histórica de los feminismos en España». Historia social, no 20 (1994), pp. 162-163; SCANLON, Geraldine, M. La polémica feminista en la España contemporánea, 1868-1974. Madrid, Akal, 1986, $2^{a}$ edic., pp. 161-194.

19. Como citaba más arriba, dicho modelo encuentra antecedentes entre las laicistas y librepensadoras estudiadas por $\mathrm{M}^{\mathrm{a}}$ Dolores Ramos (ver nota 18). Este arquetipo propuesto presenta elementos comunes con la categoría de propagandista definida por Miren Llona en su Tesis doctoral: LlonA, Miren. Entre señorita... Op. cit., p. 207, donde señala que las propagandistas junto con las estudiantes de los niveles medio y superior, las mujeres que ejercieron profesiones liberales, las religiosas y las dedicadas a la beneficencia contribuyeron con sus trayectorias a «redefinir la categoría de señorita de clase media». Sin estar en desacuerdo, quiero sugerir que dentro de las propagandistas no sólo cupieron las señoritas de clase media sino que también pertenecieron a esta categoría muchas trabajadoras manuales con distintas posturas ideológicas cuyas trayectorias he tenido ocasión de analizar (desde Mercedes Quintanilla hasta Virginia González).

20. MELUCCI, Alberto. "Asumir un compromiso: identidad y movilización en los movimientos sociales». Zona Abierta, 69 (1994), pp. 153-180 y MeluCCI, Alberto. Nomads

Feminismo/s 16, diciembre 2010, pp. 107-138 
tarios pronto se vería ampliado a otras cuestiones relacionadas con la propia subjetividad de las afiliadas. Precisamente, una de las modificaciones más significativas en la identidad de las socialistas madrileñas se originó a partir del contacto con militantes más preocupadas por la situación de las mujeres y de los cambios y experiencias que en relación con este tema estaban teniendo lugar en otros países del entorno. El planteamiento de este debate fue modificando sus objetivos y sus intenciones declaradas ${ }^{21}$ que a comienzos de los años veinte se orientaron hacia una renegociación del sistema de relaciones de género a partir de la plataforma que representaba el Partido Socialista, para dirigirse a toda la sociedad. Este viraje se hizo notar a partir de nuevas acciones dirigidas a trabajar con decisión por la reforma de ciertos artículos de los Códigos Civil (1889) y Penal (1870) vigentes, a solicitar el derecho al voto, a colaborar con los grupos sufragistas más destacados de aquella década (Unión de Mujeres de España, Asociación Nacional de Mujeres Españolas,...) $)^{22}$.

Esta breve descripción de algunos de los contenidos identitarios que definieron al grupo a lo largo de su historia es el punto de partida para el análisis de los ritos, aniversarios y símbolos que construyeron y asociaron a esa identidad. Dicho análisis nos permitirá añadir elementos significativos para aproximarnos a la imagen que ellas mismas decidieron proyectar ante la sociedad de su tiempo.

\section{Símbolos, ritos y campañas: elementos para la proyección de una imagen propia como trabajadoras y militantes socialistas}

Las afiliadas a la AFSM incorporaron, crearon y utilizaron una serie de rituales, tradiciones, himnos, banderas,... que se convirtieron en símbolos que resumían su identidad colectiva -en proceso continuo de construcción, como

\footnotetext{
of the Present. Social Movement and Individual Needs in Contemporary Society. Londres, Hutchinson Radius, 1989. Acerca de las formas a través de las que un grupo forja una identidad colectiva: BLUMER, Herbert. "The Field of Collective Behavior». En A. McClung Lee (ed.). New Outlines of the Principles of Sociology. NY, Barnes \& Noble Inc., 1946, citado por CASQUETE, Jesús. El poder de la calle. Ensayos sobre acción colectiva. Madrid, Centro de Estudios Políticos y Constitucionales, 2006, pp. 43-44 y 115-119 y nota 3 .

21. Con el concepto intenciones declaradas me refiero a «los fines que las integrantes del grupo que emprende la acción declaran perseguir con su planificación y puesta en marcha ya que éstos son los que finalmente actuarán como reclamo para las mujeres que se animen a respaldar la iniciativa a partir de las campañas de propaganda»: DEL MORAL VARGAS, Marta. Acción colectiva... Op. cit.

22. FAGOAGA, Concha. La voz y el voto de las mujeres. El sufragismo en España, 1877-1931. Barcelona, Icaria, 1985. Fagoaga, Concha y SaAvedra, Paloma. Clara Campoamor. La sufragista española. Madrid, Instituto de la Mujer, 2006.
} 
ya he explicado más arriba-, y actuaron como nexo de unión entre ellas. Además, desarrollaron nuevas tácticas que renovaron el repertorio de acción colectiva conocido y que se convirtieron en señas de actuación propias que, sumadas a la apropiación de las formas de protesta practicadas por los varones, hicieron posible el ejercicio de una ciudadanía activa que el régimen político no les había reconocido ${ }^{23}$.

La creación de unos símbolos propios comenzó a tener una importancia considerable entre las integrantes del Comité de la AFSM a partir de 1910. En aquel año se aprobó la apertura de una suscripción para la confección de su bandera y para bordar un lazo conmemorativo del triunfo en las elecciones, para la del partido ${ }^{24}$. La trascendencia de estos símbolos reside en su capacidad para dotar de identidad y cohesión al grupo que representan, al tiempo que hacen más llamativa su presencia y localización en los actos a los que se llevaban como el $1^{\circ}$ de Mayo, los congresos del partido, en el escenario de los teatros donde se celebraban mítines de propaganda y, durante los primeros tiempos, cubriendo los féretros de las afiliadas fallecidas. La bandera ponía de manifiesto la presencia de las compañeras o destacaba la pertenencia al grupo de aquellas a quienes se acompañaba al cementerio civil, convirtiéndose en un referente identitario básico ${ }^{25}$.

Otra seña de identidad para muchas de las afiliadas fue la preferencia por las ceremonias civiles al contraer matrimonio, al «bautizar» a sus hijos o con motivo de su fallecimiento o el de sus familiares. En muchas ocasiones la AFSM enviaba una o dos delegadas a tales actos, acompañadas por la bandera de la agrupación. Lo habitual de esta práctica comenzó a representar una amenaza de deterioro para la bandera debido a los frecuentes traslados. Por este motivo fue sustituida por un paño en los entierros civiles y en las actividades de otros grupos a las que se acudía mediante representación. Además, la bandera de la AFSM dejó de presentarse a los actos celebrados en la Casa del

23. JimÉnEZ Perona, Ángeles. «La construcción del concepto de ciudadanía en la modernidad». Arenal, 2:1 (1995), pp. 137-145; «Las conceptualizaciones de la ciudadanía y la polémica en torno a la admisión de las mujeres en las Asambleas». En C. Amorós (coord.). Actas del Seminario permanente: Feminismo e Ilustración, 1988-1992. Madrid, UCM, 1992, pp. 25-40.

24. ASM, Actas Comité, (18-II-1910/26-XII-1913), FPI, Archivo y Biblioteca, [FPI/ AASM-LXXII-1] y ASM, Actas Asambleas Generales, 30-IX-1905/18-XI-1917, [FPI/ AASM-LXX-2].

25. La importancia de los rituales como «mecanismo de integración grupal» y de los símbolos: CASQUETE, Jesús. Op. cit., pp. 43-51. Sobre la manifestación obrera del $1^{\circ} \mathrm{de}$ Mayo: RivAs, Lucía. Historia del $1^{\circ}$ de mayo en España. Madrid, UNED, 1987.

Feminismo/s 16, diciembre 2010, pp. 107-138 
Pueblo desde abril de 1913 «por no tener condiciones para colocarla (ya que) pudiera deteriorarse» y quedó reservada para ocasiones como el $1^{\circ}$ de Mayo.

Durante la manifestación del $1^{\circ}$ de Mayo las banderas de las sociedades obreras y de las agrupaciones políticas (ASM, JSM, AFSM) fueron el distintivo imprescindible en torno al cual se agrupaban los afiliados y afiliadas. La organización de los asistentes era anunciada año tras año en la prensa socialista de los días previos a la fiesta obrera.

En Madrid. Instrucciones a los manifestantes. Compañeros: para continuar consiguiendo el orden que caracteriza nuestras manifestaciones estimamos de interés haceros las recomendaciones que indicamos a continuación:

$1^{\circ}$ Que los trabajadores se agrupen desde el primer momento donde se halle la bandera de su sociedad o aquella otra que les haya sido designada si su sociedad no tuviese bandera, procurando no esperar la manifestación en el trayecto para unirse a ella.

$2^{\circ}$ Que guarden en la marcha con todo rigor el orden numérico designado a cada sociedad.

$3^{\circ}$ Que procuren los manifestantes dejar, durante la marcha, entre bandera y bandera, un prudencial espacio.

$4^{\circ}$ Que por conveniencia de todos se atiendan las recomendaciones especiales que los delegados de orden pudieran hacerles $(. .)^{26}$.

La primera imagen conservada que documenta la presencia de las afiliadas a la AFSM en las manifestaciones del $1^{\circ}$ de mayo en Madrid corresponde a $1911^{27}$. El orden estricto del desfile asignó en los primeros años un puesto principal a las afiliadas a la AFSM, asegurando su visibilidad al colocarlas en la cabecera, precediendo a los dirigentes de la agrupación local. La bandera de la ASM iba seguida de los niños y niñas de las escuelas laicas y, a continuación, las afiliadas a la AFSM. Más que por caballerosidad, el gesto se dirigía a mostrar que el partido contaba con una agrupación política femenina en la capital. Otras mujeres, afiliadas a las sociedades obreras, marchaban muchas filas por detrás de la cabecera. Interesaba resaltar la pertenencia de las trabajadoras al Partido Socialista y al integrarlas de forma destacada en el ritual del $1^{\circ}$ de Mayo demostraban a la población madrileña afiliada y no afiliada a la ASM que tenían un lugar entre sus militantes ${ }^{28}$. Es curioso comprobar cómo el puesto preferente del que gozaban en la fiesta más importante del socialismo no se correspondía con el lugar que, en la práctica, ocupaban en la Casa del Pueblo.

26. El Socialista, 30-IV-1914.

27. Vida Socialista, 7-V-1911. Desde 1907 se mencionaba la presencia de las afiliadas en la crónica de El Socialista.

28. CASQUeTE, Jesús. Op. cit., pp. 43-51 y 118. Los rituales de protesta son definidos como acciones sociales «simbólicas, estandarizadas y repetitivas». 
Efectivamente, las mujeres afiliadas a las sociedades de oficio en general y a la AFSM, en particular, disfrutaban de los mismos derechos que sus compañeros en el interior de la Casa del Pueblo. Participaban en las elecciones de representantes para la administración interior y, en el caso de las militantes de sociedades políticas como la AFSM, intervenían además en la elección de los candidatos del partido para dirigirlo y para presentarse a los comicios generales y municipales. Cada grupo votaba sus propuestas para los congresos y enviaba a sus representantes. Una de las líderes de la AFSM, Virginia González, ocupó cargos de máxima responsabilidad en el Partido y en la Unión General. Podemos afirmar pues que las mujeres veían reconocida la igualdad de derechos en los reglamentos de las agrupaciones socialistas y esto marcaba una notable diferencia en el contexto de la sociedad de la Restauración que les negaba esa misma igualdad en sus instituciones.

Sin embargo, en la práctica, el ejercicio del poder, entendido como «la expresión de una posibilidad particularmente grande de influir sobre la autodirección de otras personas y de participar en la determinación de su destino ${ }^{29}$, quedaba muy limitado para las afiliadas a la AFSM. La creación de una agrupación independiente les dio la posibilidad de asegurarse una representación de sus intereses en todos los foros socialistas donde se hicieron oír. Pero esta representación siempre estuvo en minoría, lo cual restaba fuerza a sus iniciativas. Durante toda su existencia se toparon con la oposición de muchos de sus compañeros que no comprendían su intervención política. Aún así, la disolución de la agrupación en 1927 demostró que, sin una organización exclusivamente femenina que las respaldara, la mayoría de las afiliadas terminarían por apartarse de los círculos de liderazgo asociativo, avasalladas por sus compañeros. Es decir, que el empeño de Virginia González por mantener agrupaciones segregadas fue del todo acertado no solo para animar a las mujeres a afiliarse sino para lograr aumentar su poder efectivo en el proceso de toma de decisiones en el interior del partido.

Retomando la cuestión de los símbolos durante el $1^{\circ}$ de mayo, las socialistas introdujeron otros elementos como la flor roja, que fue vendida por las afiliadas en varias de estas citas a beneficio de El Socialista. Por la tarde y en los años en los que estuvo prohibida la manifestación, especialmente durante la dictadura de Primo de Rivera, familias enteras de socialistas celebraban la tradicional gira campestre en las inmediaciones del Puente de los Franceses y, más tarde, en la Dehesa de la Villa.

29. Elías, Norbert. La sociedad de los individuos. Barcelona, Península, 1990, p. 72, citado por HERnANDO, Almudena. «Poder...» Op. cit., p. 88.

Feminismo/s 16, diciembre 2010, pp. 107-138 
Durante todo el tiempo en que estuvieron parados los obreros en espera de que la manifestación rompiera la marcha, las compañeras de la Agrupación Femenina Socialista estuvieron vendiendo, con gran actividad y entusiasmo, claveles y florecitas rojas a beneficio de nuestro querido diario.

En esta labor pusieron nuestras compañeras grandes entusiasmos, haciéndose dignas de un aplauso que desde aquí les enviamos cordialmente.

En muy poco tiempo fueron vendidos los 500 claveles rojos que se habían traído, lamentando las mujeres que no se hubieran adquirido más, pues seguramente el resultado habría sido aún más espléndido.

Durante el paso de la manifestación continuaron también vendiendo florecitas, hasta que se agotaron todas las que habían traído $(\ldots)^{30}$

Los himnos eran otra constante en sus campañas públicas. La renuncia a cantarlos solo tuvo lugar en las ocasiones en las que se optaba por la protesta silenciosa, como el $1^{\circ}$ de mayo de 1917 . Los mítines, las veladas, las manifestaciones se cerraban con la Marsellesa y la Internacional, en cuya entonación destacaban el Orfeón socialista y, en muchos casos, las afiliadas a la AFSM:

El domingo pasado celebró la Conjunción republicano-socialista un grandioso mitin en el Frontón Central con objeto de conmemorar el triunfo alcanzado en las últimas elecciones. (...) Puede asegurarse que entre el público había más de 1.000 mujeres, muchas de ellas pertenecientes al Grupo Femenino Socialista y algunas damas rojas. (...) Acabados los discursos, el Orfeón socialista, situado en los palcos, entonó La Marsellesa de la Paz, (...) Después, las compañeras del Grupo Femenino cantaron La Internacional siendo premiadas con entusiásticos aplausos ${ }^{31}$

Por otra parte, en los últimos años se comenzó a considerar que el envío de comisiones a los actos de homenaje a los compañeros difuntos exigía demasiada dedicación para el comité. Una de sus líderes más significativas de los años veinte, Claudina García, sugería la posibilidad de que asociaciones como Fraternidad Cívica se ocuparan de tales homenajes, liberando a las dirigentes de estos cometidos para dedicarse a otras labores de propaganda política ${ }^{32}$. La disminución en el número de afiliadas dispuestas a encabezar las iniciativas del grupo exigía una racionalización de las obligaciones inherentes al cargo.

30. El Socialista, 2-V-1915.

31. El Socialista, 20-V-1910. Sobre los himnos cantados por los socialistas: DE LUIS, Francisco. La cultura... Op. cit., p. 71.

32. GFSM, Actas de asambleas, (3-III-1912/18-IX-1926), FPI, Archivo y Biblioteca, [FPI/ AASM-LXXV-2]. Fraternidad Cívica fue una agrupación de mujeres, independiente de los colectivos socialistas, fundada para el «cuidado y adorno del cementerio civil y socorro». La idea partió de Catalina García, viuda de Nicolás Salmerón y contó con el apoyo de Miguel Morayta. En el proyecto participaron varias mujeres destacadas por su vinculación a los círculos socialistas, republicanos, comunistas y masones de la capital como Otilia Solera o Consuelo Álvarez: Del Moral Vargas, Marta: Acción... Op. cit. 
En cualquier caso, es uno de los muchos ejemplos de debate interno dentro de una agrupación que negociaba permanentemente ciertos aspectos de su acción política.

En el mismo sentido, se puede hablar de la elaboración de un calendario integrado por fechas clave, de valor negativo y positivo, con un significado compartido e integrador de los principios socialistas. Las afiliadas se sumaban a otras organizaciones en la convocatoria de actos en recuerdo de fechas como la Semana Trágica y añadieron las suyas propias con la celebración del aniversario de su fundación como grupo, muchas veces unidas a la JSM.

Por otro lado, la AFSM celebraba actos festivos durante las jornadas señaladas por el calendario católico. Una de las más habituales eran las llamadas «giras de promiscuación de Viernes Santo», que consistían sencillamente en organizar excursiones al campo para comer, celebrando una especie de antiayuno de significado laico. Además, las actas recogen una propuesta aplaudida por el resto del Comité para sugerir que la Casa del Pueblo permaneciese abierta durante la jornada del 24 de diciembre. Sin embargo, el fuerte arraigo de esta festividad católica pudo incluso con la dirección de dicha institución: «La compañera Merino propone abolir la costumbre de cerrar la Casa del Pueblo el 24 de diciembre. La compañera Norabuena recuerda que el año pasado lo hizo presente al Consejo de Administración y no lo aceptaron. El Comité pareciéndole bien la proposición no la aprueba por no ser posible» ${ }^{33}$.

Además, las acciones colectivas planificadas y organizadas por la AFSM se convirtieron en el elemento más importante a la hora de proyectar una imagen ante la opinión pública. Los asuntos que provocaron su movilización, las estrategias ideadas y la forma de conducir las preocupaciones de la población femenina hacia las convicciones socialistas y societarias son los tres aspectos a destacar en relación con la imagen del grupo.

El antimilitarismo, el desabastecimiento y los elevados precios de las subsistencias fueron objeto constante de la atención de los sucesivos comités. Así, en los meses previos a las elecciones a Cortes de 1910 las socialistas se sumaron a la campaña antimilitarista sostenida por la JSM en favor del servicio militar obligatorio, compartiendo el protagonismo en los mítines celebrados. A partir de aquel año, las mujeres socialistas desplegaron un discurso propio que apelaba a la responsabilidad política de las madres obreras, encargadas de la educación de sus hijos y, sobre todo, de la defensa de sus intereses de clase, oponiéndose activamente a las desigualdades del sistema y a la guerra. Los

33. GFSM, Actas Comité, (28-XI-1911/26-I-1916), FPI, Archivo y Biblioteca, [FPI/ AASM-LXXV-4].

Feminismo/s 16, diciembre 2010, pp. 107-138 
intentos de movilizar a las trabajadoras giraban en torno a su identidad como madres de las clases humildes.

La importancia de las madres como transmisoras de un mensaje insumiso al reclutamiento desigual volvió a convertirse en el eje sobre el que se desplegó la propaganda de la exitosa campaña contra la guerra de junio de 1913. Todo el discurso se articulaba a través de la maternidad, pieza central de la conciencia femenin $a^{34}$. Las diferencias de clase pasarían a un segundo plano si la ley que imponía el servicio militar obligatorio se ejecutase en la práctica. Aunque las protestas contra la redención a metálico se mantuvieron, se lanzó un planteamiento basado en la unión de las mujeres por el hecho de serlo, es decir, en la solidaridad de género ${ }^{35}$. Sin embargo, llama la atención que el remedio que proponían era el ingreso en las sociedades obreras como medio para transformar la situación, redirigiendo su campaña hacia la propaganda societaria.

A través de campañas como ésta, la AFSM mostraba un abanico de intenciones mucho más amplio. En los discursos afloraban los objetivos perseguidos por el Comité, sus intenciones declaradas: la necesidad de hacer conscientes a las mujeres de su poder como educadoras dentro del hogar, la importancia de dirigir esa labor hacia la difusión de los principios socialistas y la posibilidad de captar entre un auditorio excepcionalmente numeroso, atraído por un discurso centrado en la conciencia femenina, futuras afiliadas a las sociedades de oficio y políticas de la Casa del Pueblo:

He presentado el mal -concluye diciendo-, ahora os presento el remedio ofreciéndoos, madres, hermanas, amigas, compañeras de trabajo, mujeres todas; la Asociación como el medio y el remedio para la modificación y transformación del régimen. Unidas todas las obreras frente a la locura imperialista podrán decir que nones, y esa unión, produciendo infinitos bienes, evitará muchísimos males ${ }^{36}$.

El éxito de la campaña de 1913 no solo se extendió por casi todas las provincias sino que las adhesiones y felicitaciones llegaron incluso de otros países.

34. KAPLAN, Temma. «Conciencia femenina y acción colectiva: el caso de Barcelona, 19101918». En J.S. Amelang y M. Nash (eds.). Historia y género: las mujeres en la Europa moderna y contemporánea. Valencia, Alfons el Magnànim, 1990, pp. 267-295.

35. La construcción de un discurso basado en la maternidad como elemento central para la movilización de las mujeres contra la guerra no era nuevo. Tampoco lo era la reivindicación de suprimir el sistema de redención a metálico: SANFeliu, Luz. Op. cit., pp. 119-120. LORENZO, Josemi. «Tensiones militarismo/antimilitarismo». En A. Bernárdez (dir.). Escritoras y periodistas en Madrid (1876-1926). Madrid, Ayuntamiento de Madrid, 2007, p. 148. Referencias al mitin en El Socialista, 23-VI-1913.

36. El Socialista, 22-VI-1913. 
El creciente apoyo popular fue interpretado como un triunfo que merecía ser recordado imponiendo un lazo conmemorativo en la bandera. Esta decisión nos recuerda de nuevo la importancia que para estos grupos tenía el poner de manifiesto, de forma visible, a través del lazo en la bandera, su triunfo político.

Las protestas por el pan, entre las que destaca la campaña de 1915, siguieron un esquema idéntico ${ }^{37}$. Las líderes de la AFSM a través de estas acciones relacionadas con la conciencia femenina habían conseguido difundir nuevas demandas entre las trabajadoras. El antimilitarismo y el anticapitalismo se unían a la propaganda societaria en la construcción de un discurso que iba mucho más allá de las obligaciones asociadas a la maternidad. El resultado fue notables aumentos en los porcentajes de afiliación y reacciones ambivalentes entre la opinión pública, en las que me detendré más abajo.

Por otra parte, su propaganda de la candidatura de la Conjunción republicano-socialista en sucesivas citas electorales aumentó su popularidad progresivamente dentro y fuera de la Casa del Pueblo. Sus mítines tenían lugar en Madrid y en las localidades próximas a las que se desplazaban las oradoras acompañadas de su bandera y de su reglamento.

Tras el punto de inflexión que supuso el año 1917, los objetivos del grupo siguieron incorporando novedades con respecto a los fundacionales de 1906. A la propaganda socialista y societaria se unieron ahora las reivindicaciones derechos sociales y políticos para las mujeres, lo cual motivó una renovación de su imagen de cara a la opinión pública ${ }^{38}$. En 1924, Julia Vega Elejalde expresaba el interés que tendría para el socialismo trabajar por estas reivindicaciones:

(...) El movimiento feminista (...) es el más poderoso auxiliar para el Socialismo, por ir ambos conjuntamente a la misma conquista para esta pobre Humanidad, de un modo mejor, que salvaguarde los derechos de uno y otro

37. El análisis de esta campaña fue presentado en: Del Moral VARGAS, Marta. «De la protesta espontánea a la Acción Colectiva Femenina: motines por el pan en Madrid en torno a 1915». Comunicación presentada en el VIII Congreso de la Asociación Española de Historia Contemporánea, Instituto Valentín de Foronda, Vitoria-Gasteiz, 20-22 de septiembre de 2006.

38. En una de las conferencias celebradas por el comité encabezado por Claudina García como vicepresidenta, ésta volvía a insistir sobre los nuevos principios que sustentaban la propaganda del grupo centrados en la dignificación de las mujeres y en la conquista de sus derechos ciudadanos: El Socialista, 29-VI-1926. Ese espíritu igualitario de su programa también se extendió a las afiliadas a los sindicatos ugetistas que reclamaban que las mujeres fueran tenidas en cuenta para su dirección: MARUJA: «La mujer en la organización». El Socialista, 23-XII-1926.

Feminismo/s 16, diciembre 2010, pp. 107-138 
sexo. Ambos ideales, que se funden en uno mismo, ostentan en su democrática bandera idénticos lemas: Libertad y Justicia ${ }^{39}$.

La incorporación desde la segunda década del siglo de afiliadas procedentes del grupo Damas Rojas que, en muchos casos, también pertenecieron a ciertas logias femeninas fue determinante para la apuesta decidida por estos objetivos. A partir de 1918, la AFSM comenzó a colaborar con las dirigentes de otras asociaciones como la Unión de Mujeres de España y, más tarde, con la Asociación Nacional de Mujeres Españolas, para defender no solo la obtención del derecho al voto para las mujeres sino también las reformas de los Códigos Civil y Penal.

\section{Las imágenes de la afsm entre la opinión pública: visiones enfrentadas y cambios de actitud}

La recepción de la actividad de la AFSM entre la opinión pública de la España del momento no fue monolítica ni para todas sus acciones ni para cada uno de los momentos de su trayectoria política. A continuación haré un breve recorrido por las actitudes de sus propios compañeros, de las autoridades y de la opinión pública en general que ni mucho menos agotan el tema pero ofrecen una panorámica de la imagen de la que gozaron entre sus contemporáneos.

Uno de los ejemplos más elocuentes fue el cambio de actitud de muchos compañeros del partido que inicialmente se mostraron contrariados con su creación pero, tras sus primeras acciones, terminaron apoyando su existencia. Francisco Doménech, uno de los fundadores de la AFSM, acusaba a los dirigentes del partido en la capital de ser:

(...) unos grandes simplistas, como buenos latinos, y no hay que sacarlos de tres o cuatro conceptos generalizados y ya trillados. (...) Por eso... es por lo que no se ha entendido para qué se creaban las Juventudes Socialistas y los Grupos Femenino Socialistas, cuyas misiones radican ahí y ahí confinan. Al menos en Madrid, desde el primero hasta el último, nadie se explica el por qué de esas subdivisiones, salvo una parte de los mismos que forman la Juventud y el Grupo Femenino que acaba de constituirse ${ }^{40}$.

$\mathrm{Y}$ es que aun cuando aceptaron su actividad política, dirigentes como Pablo Iglesias o Andrés Saborit, asesor de la AFSM durante años, vieron la militancia femenina como una tarea auxiliar, necesaria pero nunca suficiente para la llegada del socialismo:

39. El Socialista, 20-IX-1924.

40. SABORIT, Andrés. «Recuerdos...» Op. cit.

Feminismo/s 16, diciembre 2010, pp. 107-138 
No se ha llamado a las mujeres para que hagan ellas la faena. ¡Valiente papel sería entonces el de los hombres! (...) Se os llama para que no quede reducida vuestra protesta al llanto y a la queja, sino para que cooperéis a nuestra labor y nos ayudéis en ella. No para que la acción vuestra sea la definitiva, sino para que ayudéis a la nuestra ${ }^{41}$.

Entre los afiliados no faltaron las opiniones extremas, desde los defensores a ultranza de la ideología de la domesticidad que hicieron famoso el desamparo masculino ante unos calcetines descosidos hasta el temor de aquellos que veían en las compañeras no militantes el caballo de Troya del clericalismo ${ }^{42}$. La difusión de una imagen de las mujeres que respondiera a un término medio entre ambas posiciones fue a menudo una preocupación central para la AFSM, que trataba de convencer de la necesidad de impulsar la propaganda entre las trabajadoras. A pesar de sus esfuerzos, afiliadas como Francisca Vega coincidían al destacar que los principales obstáculos que habían tenido que afrontar provenían de la oposición de los varones:

Ensalza la gran labor realizada por la Agrupación femenina en los ocho años que cuenta de vida, teniendo que luchar, ante todo, con las trabas que los hombres, de quienes vive la mujer en una absoluta dependencia, ponen a la actuación de ella por su emancipación. Explica cuan formidable puede ser la acción de la mujer en la lucha del proletariado contra el actual régimen social $^{43}$.

La cuestión de la militancia segregada frente a la conjunta en las agrupaciones locales también fue un tema de discusión recurrente. No solo se debatía una forma de organización, sino que lo que verdaderamente se ponía en juego era el porcentaje de poder que podían llegar a alcanzar las mujeres a través de sus agrupaciones. Ya vimos más arriba cómo a la altura de 1918 la propia Virginia González se veía aún obligada a apostar por el mantenimiento de las AFS.

La marcha de esta líder en 1921 para fundar el Partido Comunista Obrero privó a las AFS de una de sus defensoras con mayor autoridad dentro del socialismo ${ }^{44}$. Seis años después el grupo se disolvía. A falta de actas donde se declaren las causas de esta decisión, todo parece apuntar hacia un cambio

41. El Socialista, 22-VI-1913. Para Andrés Saborit, la AFSM jamás logró completar esa misión.

42. Ambos ejemplos en El Socialista, 29-IV-1910 y 1-V-1911, respectivamente.

43. El Socialista, 21-IV-1913.

44. Del Moral Vargas, Marta. Acción... Op. cit. El Partido Comunista de España creado tras el I Congreso nacional celebrado en Madrid (14/20-III-1922), estableció una secretaría femenina dirigida por Virginia González, a imagen de otros partidos comunistas como el francés: KlejMAn, Laurence y ROCHEFORT, Florence. L'égalité en marche. Le féminisme sous la Troisième République. Paris, Presses de la Fondation Nationale des Sciences Politiques, 1989, p. 233.

Feminismo/s 16, diciembre 2010, pp. 107-138 
de estrategia. Las reformas legales introducidas por la dictadura de Primo de Rivera, sumadas a la lucha planteada desde entonces por los distintos grupos políticos para atraer las simpatías de la población femenina, debieron de jugar un papel fundamental. La insistencia del PSOE por hacer ver a la ciudadanía que él mismo encarnaba la única alternativa que había incluido en su programa el sufragio universal real y sus llamamientos a la población femenina para que entrase a formar parte de la militancia activa se contraponían, quizá, con el hecho de que las mujeres tuvieran que afiliarse a un grupo segregado de la agrupación local. Lo que durante muchos años había sido un instrumento para facilitar el acceso de las mujeres a las organizaciones políticas de la Casa del Pueblo podría ser interpretado ahora como una relegación de esa parte de la militancia a un segundo plano. Dar una imagen de unidad entre hombres y mujeres, de igualdad en la militancia sin distinción de sexos, proyectaría en la cotidianeidad socialista lo que reivindicaban para los órganos de gestión local y nacional. Por otro lado, el viraje ideológico que estaban marcando las dirigentes de la agrupación en sus últimos meses al incorporar muchas reivindicaciones en favor de la igualdad entre hombres y mujeres pudo asustar a la dirección del partido en el sentido de temer un cambio de prioridades en los objetivos centrales de la misma.

Mientras gestionaron su propia agrupación política e impulsaron sus propias campañas de propaganda, las socialistas disfrutaron de la capacidad de autoafirmación que encontraban dentro de su propio círculo y que proyectaban dentro del campo socialista ${ }^{45}$. Sin embargo, la disolución de aquella y su integración en la agrupación local les restó representatividad dentro de los órganos de gestión de la Casa del Pueblo y del Partido, a excepción tan solo del cargo de vocal de la ASM ocupado por Luz García, en 1928, y Victoriana Herrero desde marzo de $1930^{46}$. Todo ello debió de hacerles más vulnerables a las actitudes de rechazo de sus propios compañeros. La pérdida del instrumento de propaganda específico que suponía la existencia de un grupo femenino debió de tener además consecuencias directas en el descenso de la afiliación entre las mujeres, a partir de entonces. De ahí el intento por parte de las hermanas García de refundar la AFSM apenas tres años después de su diso-

45. El concepto de campo según la definición de Bourdieu, Pierre. Razones prácticas... Op.cit. y La dominación masculina... Op.cit.

46. Ambas ocuparon los cargos de secretaria de actas y presidenta durante algunas sesiones del Comité por ausencia de sus compañeros: ASM, Actas del Comité, (24-IX-1927/18V-1929), FPI, Archivo y Biblioteca, [FPI/AASM-LXXIII-2], y ASM, Actas del Comité, (1-VI-1929/27-XII-1930), FPI, Archivo y Biblioteca, [FPI/AASM-LXXIII-3]. El Sol, 30-III-1930. 
lución: «(la propuesta) de las compañeras Luz y Claudina García consistente en que se forme el Grupo Femenino dentro de la Agrupación es rechazada por entender que todos debemos tener los mismos derechos y deberes, sin distinción de sexos» ${ }^{47}$.

Por otro lado, desde el punto de vista de las autoridades, la actividad política de las mujeres socialistas era tolerada bajo la atenta mirada de los censores. Todos sus mítines, como en el caso de sus compañeros, quedaban bajo la supervisión de los representantes del Estado. Además, las campañas que alcanzaron un mayor eco entre la opinión pública fueron limitadas ante el temor de que se convirtieran en actos revolucionarios. Así sucedió con la importantísima campaña contra la guerra de Marruecos de 1913, cuya manifestación fue prohibida porque, según el Ministro de la Gobernación, Santiago Alba: «Si se hubiera tratado -dijo- de una manifestación de mujeres solas, el Gobierno la autorizaría, pero se habla de banderas, y se mezcla a Sociedades obreras y otros elementos y eso ya no puede ser ${ }^{48}$.

Por otro lado, la huelga de 1917 puso en evidencia cómo los representantes del régimen de la Restauración prefirieron negar la participación efectiva de las mujeres en los movimientos revolucionarios. Virginia González, integrante del comité de huelga, detenida junto a sus compañeros en la vivienda de la calle del Desengaño, no fue condenada tan duramente como éstos. La ideología de la domesticidad imperante fue utilizada como venda y excusa respectivamente por la acusación y la defensa de la líder más destacada del partido para disimular la realidad de la intervención política efectiva de las trabajadoras en el movimiento obrero.

Por un lado, los defensores del comité ante los tribunales articularon la defensa de Virginia González en torno al hecho de que, al tratarse de una mujer, no podía estar presente en aquella reunión más que para desempeñar las labores asignadas a su condición femenina: «Virginia González sólo estuvo en la casa para ayudar en los quehaceres domésticos» ${ }^{49}$. La declaración de Virginia en la causa instruida contra el comité de huelga coincide con los argumentos esgrimidos en su defensa. Asumía, de este modo, la estrategia con mayores posibilidades de éxito para eludir la condena más dura:

Que cuando fue detenida se encontraba en el número doce de la calle Desengaño desde el sábado once del actual por haberla encargado un compañero

47. ASM, Actas Asambleas Generales, (26-II-1927/21-XII-1932), FPI, Archivo y Biblioteca, [FPI/AASM-LXXI-1].

48. El País, 3-VII-1913. SCANLON, Geraldine M. Op. cit., p. 234.

49. Se trata de las palabras pronunciadas por la defensa que fueron publicadas en El País, 30-IX-1917. 
cuyo nombre no recuerda ni el domicilio, para que se personase en dicha casa con el fin de asistir a los compañeros que firman el manifiesto y que se la hizo saber que estaban allí ocultándose de la policía que trataba de detenerlos y en la citada casa conoció a Juana Sanabria, la que no pertenece a ninguna organización política ni económica del partido socialista. Que durante las horas que los respectivos compañeros se reunían para sus trabajos no permaneció con ellos la declarante, ignorando también cuáles fueron aquellos y en cuyas horas acompañaba la declarante a Juana Sanabria ${ }^{50}$.

Por otro lado, resulta sorprendente comprobar cómo Virginia González no fue condenada como integrante del comité cuando era de dominio público su destacada actividad propagandística dentro del Partido Socialista. De hecho ocupaba el cargo de vocal del Comité Nacional del PSOE desde 1915 y de la UGT desde mayo de 1916 (no abandonaría ninguno de los dos hasta 1918). Sus detenciones, las intervenciones en todo tipo de actos políticos, su fama entre los afiliados y afiliadas de todo el país, sus iniciativas para modificar la legislación obrera que afectaba a las trabajadoras,... eran de sobra conocidas tanto por las fuerzas de orden público como por las autoridades políticas. Ella fue, según la prensa, la única que opuso resistencia a ser detenida y trató de eliminar los documentos que implicaban a los reunidos en la casa de la calle del Desengaño:

Entre los documentos encontrados al hacer el registro en la casa donde fueron detenidos los individuos del Comité de huelga, figuran itinerarios de las cuencas mineras, puntos donde hay instalados talleres ferroviarios, claves y una proclama en la que se dan instrucciones a los revoltosos, sumamente completas.

(...) Parece que en otro de los documentos hallados figura otro donde constan los nombres de los personajes que habían de dirigir los destinos públicos en caso de que triunfase el movimiento sedicioso ${ }^{51}$.

Parecía como si, con una pena insignificante comparada con la dictada contra el resto del comité ${ }^{52}$, la parte de la sociedad que dictaba las normas se negara

50. Expediente Huelga 1917, Archivo Militar de Segovia, Sección $9^{a}$.

51. El Debate, 16-VIII-1917. «Virginia, después de una larga incomunicación y no obstante haberse solidarizado ante el juez militar con toda la actuación de sus compañeros, se benefició de un sobreseimiento»: Del Rosal, Amaro. Historia de la UGT. Barcelona, Guijarro, 1977, Vol. I, p. 160. «No fue encarcelada porque tuvimos buen cuidado de descartarla en nuestras declaraciones ante la autoridad militar, a quien hicimos creer que estaba con nosotros para prepararnos la comida y asistirnos convenientemente»: SABORIT, Andrés. Apuntes históricos: Pablo Iglesias, UGT, PSOE. Fundación Pablo Iglesias, Archivo y Biblioteca, AASC-XXVII-XXXVI.

52. Virginia González fue condenada a un año y ocho meses de prisión y 21 días de destierro y al pago de una multa de 780 pesetas: AMS, Sección $9^{a}$. Aunque su expediente recoge esta condena otras fuentes señalan que tanto Juana Sanabria como Virginia 
a admitir el ejercicio de un poder efectivo por parte de una mujer en el comité director de la huelga. De paso evitaban que otras mujeres pudieran llegar a ver en Virginia un modelo de mujer crítica con el sistema político de la Restauración, entendido en su sentido más amplio. La comparación con la situación del resto de sus compañeros es escandalosa ya que fueron condenados a reclusión perpetua que solo finalizó tras el veredicto dictado por los votantes ante las urnas.

Por último, por lo que se refiere a la opinión pública en general, encontramos actitudes muy diversas que no pueden ser comentadas en su totalidad en este artículo. Aun así me gustaría citar la postura del catolicismo social y la de un sector de las clases trabajadoras no militantes.

En relación con los primeros no hay que olvidar que la fundación del Sindicato Católico de la Inmaculada supuso una reacción defensiva por parte de ciertos grupos católicos de la sociedad española al protagonismo ganado por las organizaciones obreras entre las trabajadoras.

Los socialistas están trabajando cuanto pueden para atraer a su partido y organizar a la mujer, y aquí, en la Casa del Pueblo, tienen ya establecidas una sociedad de sastras, otra de modistas, otra de lavanderas y planchadoras, y un grupo femenino socialista, sin que haya podido averiguar el número más o menos aproximado de las que en ellas se hayan inscrito (...) y nosotros, los católicos (...) ¿Dejaremos que se nos adelanten, como se nos adelantaron ya en la organización de los obreros? ?3 $^{53}$

Esa rivalidad se mantuvo a lo largo de toda la vida del grupo y fue el origen de los mayores enfrentamientos sostenidos por la AFSM. La tensión se acentuó tras el nombramiento de las primeras concejalas en el Consistorio madrileño -1924-, entre quienes se encontraba María de Echarri, fundadora y dirigente de los sindicatos católicos de obreras en Madrid. Su propuesta de retirar las subvenciones a las escuelas laicas de la capital fue uno de los motivos de disputa entre la propagandista católica y las socialistas de la Casa del Pueblo:

Luego, en el turno de espontáneos, habla nuestra compañera Carmen González. Dice que aunque pidió ella la palabra, representa a la Agrupación Femenina Socialista y a las trabajadoras madrileñas.

(...) protestó del acuerdo últimamente tomado por el Ayuntamiento, a propuesta de la señorita Echarri, quitando las subvenciones del Ayuntamiento a las escuelas laicas y neutras. Ese acuerdo es atentatorio a la libertad de conciencia. Nosotras, que somos madres, queremos educar a nuestros hijos

González fueron «libremente absueltas»: Huelga general de Agosto de 1917. La condena del Comité de huelga. Acusación, defensa y sentencia del Consejo de guerra. México, Editorial Pablo Iglesias, 1950, p. 30.

53. SANTANDER, Juan José. Acción sindical femenina. Madrid, La Editora, 1914, pp. 8-10.

Feminismo/s 16, diciembre 2010, pp. 107-138 
con arreglo a los dictados de nuestra conciencia, y por eso los mandamos a esas escuelas. Si las ideas son todas respetables y nosotras respetamos las de la señorita Echarri, ella debe respetar también las nuestras.

Pide que ese acuerdo sea derogado y que las subvenciones sean distribuidas como en años anteriores entre todas las escuelas, católicas y no católicas ${ }^{54}$.

Por último, las referencias hacia las actitudes de la población no militante son diversas y, en muchos casos contrapuestas. Como ejemplo de actitudes contrarias a la agrupación, en 1912 sufrían el desprecio de un grupo de espectadores con motivo de la marcha del día del trabajo: «Lectura de un comunicado de la Agrupación Socialista de Bicálbaro [sic] haciendo causa común en la protesta contra los insultos de que fuimos objeto en la manifestación del $1^{\circ}$ de Mayo ${ }^{55}$.

Sin embargo, durante las protestas populares por las subsistencias que tuvieron lugar entre el 28 y el 29 de febrero de 1919, un grupo de ciudadanos de clase obrera no militante recurrieron a ellas para que defendieran sus intereses. Durante aquellos días las requisas de pan y comestibles debidas al desabastecimiento ocasionaron importantes disturbios y la detención de unos trescientos ciudadanos ${ }^{56}$. Entre ellos, se encontraban al menos 119 mujeres cuyas causas se instruyeron a partir del día 1 de marzo por delitos de sedición. Aunque las mujeres de la AFSM no se ocuparon de estas protestas, los familiares de las presas se dirigieron a la Casa del Pueblo para tratar de obtener apoyos que les libraran del presidio. Es decir que para estos ciudadanos la Casa del Pueblo constituía un referente al que acudir para pedir ayuda ante las injusticias sociales cometidas por las autoridades contra las mujeres. Las sucesivas campañas por las subsistencias emprendidas por la Casa del Pueblo, entre las que destacó la organizada por la AFSM debieron de ser tenidas en cuenta por aquellos que solicitaban su mediación:

54. El Socialista, 18-III-1925. También, El Heraldo de Madrid, 18-III-1925. El Heraldo de Madrid, 17-III-1925. María Cambrils desde su columna del diario socialista criticaba la labor de María de Echarri no sólo en el Ayuntamiento, sino también como propagandista y escritora: El Socialista, 3-VI-1925. Esta disputa también se analiza en un trabajo de próxima aparición: GÓMEZ-FERRER, Guadalupe y DEL MORAL, Marta. «Las pioneras en la gestión local: concejalas y alcaldesas designadas durante la dictadura de Primo de Rivera y los gobiernos Berenguer y Aznar (1924-1930)». En G. Nielfa (dir.). El acceso de las mujeres a los poderes locales (en preparación).

55. GFSM, Actas Comité (28-XI-1911/26-I-1916), FPI, Archivo y Biblioteca, [FPI/ AASM-LXXV-4].

56. La descripción de los sucesos y una interpretación de sus causas en: SÁNCHEZ PÉREZ, Francisco. La protesta de un pueblo. Acción colectiva y organización obrera. Madrid, 19011923. Madrid, Cinca, 2006, pp. 82-92. 
Nos ha visitado una nutrida comisión de vecinos del barrio del Pacífico para denunciarnos que todos ellos tienen parientes que han sido encarcelados ayer de la manera más absurda e ilegal. (...) se efectuaron registros domiciliarios a viva fuerza y se arranca a hombres y mujeres de sus casas para llevarlos al Juzgado de Guardia, por el enorme delito de poseer una simple lata de sardinas.

Hay más de 50 mujeres presas, una de ellas está encinta, y las autoridades han llegado en su delirio represivo a detener a menores de catorce años. (...)

Un grupo muy numeroso de mujeres fue esta mañana a la Casa del Pueblo a protestar contra las detenciones arbitrarias de que son objeto muchas mujeres y niños por supuesta intervención por los hechos ocurridos el día del saqueo. Todas ellas hacen manifestaciones de inocencia y piden la libertad de los detenidos (...) El Consejo de Dirección de la Casa del Pueblo hará la oportuna reclamación al Gobierno ${ }^{57}$.

Las trabajadoras de algunos sectores también acudieron a la secretaría de la AFSM para solicitar apoyo en medio de paros convocados sin la planificación necesaria. En 1915 tuvo lugar una huelga de paragüeras que no fue recogida en las estadísticas. Las trabajadoras pidieron auxilio a la AFSM que delegó en la Sociedad de Profesiones y Oficios Varios el proyecto de asociarlas. Su situación era precaria ya que las paragüeras, desconocedoras e inexpertas en las estrategias de lucha sindical, habían iniciado un conflicto sin haber constituido previamente una asociación y sin contar con caja de resistencia ${ }^{58}$ :

La compañera Taboada que las güelguistas [sic] Paragüeras piden alluda [sic] pero poco seria. La compañera Posadas opina no debemos comprometernos por $\mathrm{q}^{\mathrm{e}}$ lla [sic] emos [sic] y las emos [sic] animado a $\mathrm{q}^{\mathrm{e}}$ [sic] se asocien y $\mathrm{q}^{\mathrm{e}}$ [sic] son trabajadores hace 30 años y no se an [sic] visto con nosotras ni se han asociado, el Comité acuerda $\mathrm{q}^{\mathrm{e}}$ [sic] sin que nos oficie la Varia ( $\mathrm{q}^{\mathrm{e}}$ [sic] es la $\mathrm{q}^{\mathrm{e}}$ [sic] se entiende en este asunto) no haremos nada ${ }^{59}$.

Otros ejemplos del prestigio que alcanzaron a través de sus acciones los encontramos a escala nacional e internacional. Su ejemplo motivó la solicitud de reglamentos y la fundación de grupos femeninos siguiendo el modelo de la AFSM en más de 30 localidades. Además, mantuvieron correspondencia con las líderes del movimiento de mujeres socialistas de varios países y con otras

57. El Socialista, 2 y 4-III-1919. Efectivamente, el 7 de marzo trasladaron su queja, de la que no se ocupó la AFSM. Casi todas las procesadas fueron puestas en libertad ese mismo día o poco después: Archivo Penitenciario Victoria Kent, 1919.

58. Las estadísticas oficiales no recogieron todas las huelgas, tal y como reconocieron los responsables de elaborarlas. La huelga de paragüeras no figura en las publicaciones del Instituto de Reformas Sociales, aunque sí fue seguida por la prensa: Instituto de Reformas Sociales. Estadística de huelgas: 1915 y 1916. Memoria que presenta la sección $3^{a}$ técnico-administrativa. Madrid, IRS, 1918, pp. 60-61. El Socialista, 16-VI-1915.

59. GFSM, Actas Comité, (28-XI-1911/26-I-1916), FPI, Archivo y Biblioteca, [FPI/ AASM-LXXV-4].

Feminismo/s 16, diciembre 2010, pp. 107-138 
agrupaciones femeninas de diverso carácter de Europa y Latinoamérica. Clara Zetkin se interesó por la actividad de las madrileñas y reclamó el envío de una representación española al congreso internacional de mujeres socialistas. La escasez de recursos y el desconocimiento de otras lenguas hacía imposible plantear el envío de alguna delegada:

Compañera secretaria da lectura del III Congreso Internacional que nos manda la compañera Clara Zecriln [sic] Compañera Juana dice quay [sic] que mandar una representación y se acuerda que si va algún compañero que nos represente i [sic] que se abra una suscripción permanente para cuando lleguen estos casos tengamos fondos ${ }^{60}$.

\section{Conclusiones}

Como balance hay que resaltar que la AFSM inauguró un espacio de reflexión y discusión exclusivamente femenino dentro del marco de un partido que había de tenerlas en cuenta en sus órganos de gestión y decisión a pesar de que el régimen de la Restauración les negaba el derecho a participar en la política institucionalizada. Su actividad fue decisiva en el desarrollo de un conjunto de reivindicaciones que abarcaron desde la defensa de los derechos de las mujeres vinculados a su propia conciencia femenina hasta la demanda de un nuevo contrato sexual basado en la igualdad entre hombres y mujeres. Sus estrategias renovaron el bagaje de las formas de protesta acumulado hasta el momento. Su actividad modificó en la práctica las pautas de actuación del partido en relación con sus militantes mujeres y forzó un cambio de actitud de los afiliados hacia sus compañeras que se hizo extensivo a otras agrupaciones políticas durante los gobiernos de Berenguer y Aznar. Dieron la posibilidad de socializarse en la práctica política a dos generaciones de trabajadoras cuya trayectoria continuó activa y se intensificó en muchos casos durante la II República.

De hecho, su ejemplo constituyó un referente simbólico cuya influencia se tradujo en la constitución de otros grupos femeninos socialistas en diversas localidades del país y en la aparición de nuevos colectivos de mujeres nacidos por oposición de criterios y/o estrategias como los sindicatos católicos o ciertos grupos sufragistas. El respaldo mayoritario por parte de los socialistas de la enmienda de Clara Campoamor sobre el voto femenino ha de interpretarse como un producto, si no exclusivo, sí resultado en parte de la trayectoria de las mujeres socialistas durante los años anteriores a la votación. El hecho de que el PSOE incorporara en su programa el derecho al voto desde fechas bien

60. Ídem. 
tempranas en consonancia con el resto de los partidos socialistas europeos había demostrado no ser suficiente para despejar el temor de cada uno de los diputados socialistas al voto pretendidamente conservador de las mujeres españolas en 1931 (recuérdese la abstención del Sr. Prieto y los esfuerzos del Sr. Cordero por exigir a sus correligionarios que acataran la disciplina del partido, «logrando hacer votar a muchos», según Clara Campoamor ${ }^{61}$.

En definitiva, protagonizaron la conquista efectiva de una ciudadanía que les era negada, modificando de este modo la relación de las mujeres españolas con la participación política. La alteración de esa dinámica constituyó un precedente fundamental que, sumado a otras muchas iniciativas lideradas por los grupos femeninos de la época, empujaron al reconocimiento de la igualdad de derechos con el cambio de régimen político en 1931.

\section{Referencias bibliográficas}

Amorós, Celia. Tiempo de feminismo. Sobre feminismo, proyecto ilustrado y postmodernidad. Madrid, Cátedra, 1997.

BizCARRONDO, Marta. "Los orígenes del feminismo socialista en España». En La mujer en la Historia de España (siglos XVI-XX), Actas de las II Jornadas de Investigación Interdisciplinaria, Madrid, SEM de la UAM, 1984, pp. 137-159.

Bock, Gisela. La mujer en la historia de Europa. Barcelona, Crítica, 2001.

BOURDIEU, Pierre. Razones prácticas, sobre la teoría de la acción. Barcelona, Anagrama, 1997.

- La dominación masculina. Barcelona, Anagrama, 2000.

CAPEL, Rosa Ma. «Mujer y trabajo en la España de Alfonso XIII». En R. M ${ }^{a}$ Capel (coord.). Mujer y sociedad en España (1700-1975). Madrid, Instituto de la Mujer, 1986 (1ª edición, 1982), pp. 207-238.

- El trabajo y la educación de la mujer en España, (1900-1930). Madrid, Ministerio de Cultura, Instituto de la Mujer, 1986.

- «La mujer en España. De la 'Belle Époque’ a la Guerra Civil». En El voto de las mujeres, 1877-1978. Madrid, Editorial Complutense, 2003, pp. 51-67.

CASQUETE, Jesús. El poder de la calle. Ensayos sobre acción colectiva. Madrid, Centro de Estudios Políticos y Constitucionales, 2006.

DE LUIS, Francisco. «Las Juventudes Socialistas como frente cultural pedagógico del socialismo español: el caso madrileño, 1903-1914». Historia Contemporánea, 8 (1992), pp. 249-250.

- La cultura socialista en España, 1923-1930: propósitos y realidad de un proyecto educativo. Madrid, Universidad de Salamanca, CSIC, 1993.

61. CAMPOAmor, Clara. El voto femenino y yo. Mi pecado mortal. Sevilla, Instituto Andaluz de la Mujer, 2001 (Edición original, 1936).

Feminismo/s 16, diciembre 2010, pp. 107-138 
Del Moral Vargas, Marta. «El Grupo Femenino Socialista de Madrid (19061914): pioneras en la acción colectiva femenina». Cuadernos de Historia Contemporánea, 27 (2005), pp. 247-269.

- «De la protesta espontánea a la Acción Colectiva Femenina: motines por el pan en Madrid en torno a 1915». Comunicación presentada en el VIII Congreso de la Asociación Española de Historia Contemporánea, Instituto Valentín de Foronda, Vitoria-Gasteiz, 20-22 de septiembre de 2006.

- Acción colectiva femenina en Madrid, 1909-1931. Tesis inédita dirigida por la Dra. Gloria Nielfa Cristóbal, UCM, Madrid, 14-XII-2009.

Del Rosal, Amaro. Los congresos obreros internacionales en el siglo XIX: de la joven Europa a la Segunda Internacional. México, Grijalbo, 1958.

- Los congresos obreros internacionales en el siglo XX. Barcelona, Grijalbo, 1975.

- Historia de la UGT. Barcelona, Guijarro, 1977, Vol. I.

Elías, Norbert. La sociedad de los individuos. Barcelona, Península, 1990.

ESPIGADO, Gloria. «Las mujeres en el anarquismo español (1869-1939)». Ayer, 45 (2002), pp. 39-72.

- «Las mujeres en el nuevo marco político». En G. Gómez-Ferrer, G.. Cano, D. Barrancos y A. Lavrin (coords.). Historia de las mujeres en España y en América Latina. Vol. III: Del siglo XIX a los umbrales del XX, Madrid, Cátedra, 2006, pp. 27-32.

Esteban, Jorge de. Constituciones españolas y extranjeras. Madrid, Taurus, 1979.

EVANS, Richard. Las feministas. Los movimientos de emancipación de la mujer en Europa, América y Australasia, 1840-1920. Madrid, Siglo XXI, 1980.

FAGOAGA, Concha. La voz y el voto de las mujeres. El sufragismo en España, 18771931. Barcelona, Icaria, 1985.

- y SAAVEDRA, Paloma. Clara Campoamor. La sufragista española. Madrid, Instituto de la Mujer, 2006.

FERNÁNDEZ, Arturo. Leyes electorales españolas de diputados a Cortes en el siglo XIX. Estudio histórico y jurídico-político. Madrid, Civitas, 1992.

FRAISSE, Geneviève. Musa de la Razón. La democracia excluyente y la diferencia de los sexos. Madrid, Cátedra, 1991.

FRANCO RUBIO, Gloria. La incorporación de la mujer a la Administración del Estado, Municipios y Diputaciones: 1918-1936. Madrid, Ministerio de Cultura, 1981.

- «La contribución de la mujer española a la política contemporánea: de la Restauración a la guerra civil (1878-1939)». En R.M. Capel (coord.). Mujer y sociedad en España (1700-1975). Madrid, Instituto de la Mujer, 1986 (1 ${ }^{\text {a }}$ edición, 1982), pp. 237-263.

GILlEsPIE, Richard. Historia del Partido Socialista Obrero Español. Madrid, Alianza, 1991.

GÓMEZ-FERrer, Guadalupe y Del MORAL, Marta. «Las pioneras en la gestión local: concejalas y alcaldesas designadas durante la dictadura de Primo de 
Rivera y los gobiernos Berenguer y Aznar (1924-1930)». En G. Nielfa (dir.). El acceso de las mujeres a los poderes locales (en preparación).

GONZÁLEZ QUINTANA, Antonio. «La primera organización de jóvenes proletarios españoles: las Juventudes socialistas de España o el fracaso de una alternativa juvenil de clase (1903-1921)». Studia Historica. Historia Contemporánea. 5:4 (1987), pp. 21-46.

- y Martín NÁjera, Aurelio. Apuntes para la historia de las Juventudes socialistas de España. Madrid, FPI, 1983.

HERNANDO, Almudena (coord.). «El espacio no es necesariamente un lugar. En torno al concepto de espacio y a las implicaciones de su uso en la Prehistoria». Arqueología espacial, 21 (1999), pp. 7-27.

- (coord.). La construcción de la subjetividad femenina. Madrid, Instituto de Investigaciones Feministas, UCM, 2000.

- «Hombres del tiempo y mujeres del espacio: individualidad, poder e identidades de género». Arqueología espacial, 22 (2000), pp. 23-44.

- Arqueología de la identidad, Madrid, Akal, 2002.

- ¿Desean las mujeres el poder? Madrid, Minerva, 2003.

JimÉnez PeronA, Ángeles. «Las conceptualizaciones de la ciudadanía y la polémica en torno a la admisión de las mujeres en las Asambleas». En C. Amorós (coord.). Actas del Seminario permanente: Feminismo e Ilustración, 1988-1992. Madrid, UCM, 1992, pp. 25-40.

— «La construcción del concepto de ciudadanía en la modernidad». Arenal, 2:1 (1995), pp. 137-145.

KAPLAN, Temma. "Conciencia femenina y acción colectiva: el caso de Barcelona, 1910-1918». En J.S. Amelang y M. Nash (eds.). Historia y género: las mujeres en la Europa moderna y contemporánea. Valencia, Alfons el Magnànim, 1990, pp. 267-295.

KLEJMAN, Laurence y ROCHEFORT, Florence. Légalité en marche. Le féminisme sous la Troisième République. Paris, Presses de la Fondation Nationale des Sciences Politiques, 1989.

LORENZO, Josemi. «Tensiones militarismo/antimilitarismo». En A. Bernárdez (dir.). Escritoras y periodistas en Madrid (1876-1926). Madrid, Ayuntamiento de Madrid, 2007, pp. 124-162.

LlONA, Miren. Entre señorita y garçonne: historia oral de las mujeres bilbainas de clase media (1919-1939). Málaga, Universidad de Málaga, 2002.

Melucci, Alberto. Nomads of the Present. Social Movement and Individual Needs in Contemporary Society. Londres, Hutchinson Radius, 1989.

- «Asumir un compromiso: identidad y movilización en los movimientos sociales». Zona Abierta, 69 (1994), pp. 153-180.

NASH, Mary. Mujer y movimiento obrero en España, 1931-1939, Barcelona, Fontamara, 1981.

Feminismo/s 16, diciembre 2010, pp. 107-138 
- «Experiencia y aprendizaje: la formación histórica de los feminismos en España». Historia social, 20 (1994), pp. 151-172.

- «Identidades, representación cultural y discurso de género en la España contemporánea». En P. Chalmeta, F. Checa y otros. Cultura y culturas en la historia, 94 (1995), pp. 195-203.

- Mujeres en el mundo. Historia, retos y movimientos. Madrid, Alianza, 2004.

OFFEN, Karen. «Definir el feminismo: un análisis histórico comparativo». Historia social, 9 (1991), pp. 116-128.

- European feminisms, 1700-1950. Stanford, Stanford University Press, 2000.

Pateman, Carole. El contrato sexual. Barcelona, Anthropos, 1995.

RALLE, Michel. «Les socialistas madrilènes au quotidien, I (des origines de l'agrupation a 1910)». Mélanges de la Casa de Velázquez, XVII (1981), pp. 321-345.

RAMOS, $\mathrm{M}^{\mathrm{a}}$ Dolores. «Feminismo y Librepensamiento en España. Contra las raíces de la sociedad patriarcal». En C. Canterla (coord.). VII Encuentro de la Ilustración al Romanticismo. Cádiz, Universidad de Cádiz, 1994, pp. 313-330.

- «La construcción de la ciudadanía femenina: las librepensadoras (18981998)». En C. Fagoaga (coord.). 1898-1998. Un siglo avanzando hacia la igualdad de las mujeres. Madrid, CAM, 1999, pp. 91-116.

— «La cultura societaria del feminismo librepensador (1895-1918)». En D. Bussy Genevois (dir.). Les Espagnoles dans l'histoire. Une sociabilité démocratique, (XIXe-XXe siècles). Presses Universitaires de Vincennes, Saint-Denis, 2002, pp. 103-124.

- «La República de las librepensadoras (1890-1914): laicismo, emancipismo, anticlericalismo». Ayer, 60 (2005), pp. 45-74.

- «Hermanas en creencias, hermanas de lucha. Mujeres racionalistas, cultura republicana y sociedad civil en la Restauración». Arenal, 11:2 (2004), pp. 27-56.

RIVAS, Lucía. Historia del $1^{\circ}$ de mayo en España. Madrid, UNED, 1987.

SÁNCHEZ PÉREZ, Francisco. La protesta de un pueblo. Acción colectiva y organización obrera. Madrid, 1901-1923. Madrid, Cinca, 2006.

SANFEliU, Luz. Republicanas: identidades de género en el blasquismo (1895-1910). Valencia, Universidad de Valencia, 2005.

SCANLON, Geraldine, M. La polémica feminista en la España contemporánea, 18681974. Madrid, Akal, 1986, $2^{a}$ edic.

SOWERWInE, Charles. Les femmes et le socialisme. Paris, Presses de la Fondation Nationale des Sciences Politiques, 1978. 